4. Morze, N.V., Vember, V.P., Gladun, M.A. (2019) 3D mapping of digital competence in the education system].

5. Sadovyi, M. I. (2017), Yakist profesiynoyi pidhotovky maybutnikh uchyteliv fizyky [The quality of the training of future physics teachers]. Kamianets-Podilskyi.

6. Tryfonova, O.M. (2018) Informatsiyno-tsyfrova kompetentnist': zarubizhnyy ta vitchyznyanyy dosvid [Information and digital competence: foreign and domestic experience]. Kropivnitskyi

7. Forsait ekonomiky Ukrainy [Foresight of the Ukrainian economy]

8. „Tsyfrova shkola”. Prezentatsiia kontseptsii natsionalnoho osvitnoho proektu. ["Digital School". Presentation of the concept of the national educational project].

9. Arduino pro mini.

10. Pro Natsionalnu stratehiiu rozvytku osvity v Ukraini na period do 2021 roku [About the National Strategy for the Development of Education in Ukraine for the period up to 2021]

11. Hi Tech Office Ukraine za uchastiu SFII: napriamok - tsyfrovizatsiia osvity [Hi Tech Office Ukraine with the participation of SFII: direction - digitalization of education].

\section{ВІДОМОСТІ ПРО АВТОРІВ}

МАРТИНЮК Олександр Олександрович аспірант кафедри експериментальної фізики та інформаційно-вимірювальних технологій Східноєвропейський національний університет імені Лесі Українки. kartuvannya tsifrovoYi kompetentnosti $v$ sistemi osviti [3D

Наукові інтереси: засоби формування цифрової компетентності учнів, інноваційні технології, інформаційна безпека.

МАРТИНЮК Олександр Семенович - доктор педагогічних наук, доцент, професор кафедри експериментальної фізики та інформаційно вимірювальних технологій Східноєвропейського національного університету, м. Луцьк.

Наукові інтереси: інформаційно-комунікаційні технології, мікроелектроніка, навчальний фізичний експеримент, теорія та методика навчання фізики.

\section{INFORMATION ABOUT THE AUTHOR}

MARTYNIUUK Oleksandr Oleksandrovych graduate student of pedagogical sciences, associate professor, professor of the department of experimental physics and information and measurement technologies of the Lesia Ukrainka Eastern European National University, Lutsk.

Circle of research interests: means of forming students' digital competence, innovative technologies, information security.

MARTYNIUUK Oleksandr Semenovych - doctor of pedagogical sciences, associate professor, professor of the department of experimental physics and information and measurement technologies of the Lesia Ukrainka Eastern European National University, Lutsk.

Circle of research interests: information and communication technologies, microelectronics, educational physical experiment, theory and methods of teaching physics.

Стаття надійшла до редакиії 23.09.2020 p.

\section{УДК 378.14}

DOI: 10.36550/2415-7988-2020-1-191-242-246
МИЧКА-ЛЕВЧЕНКО ЮЛія ЗоЛТанівна аспірантка кафедри педагогіки та інноваційної освіти, Національний університет «Львівська політехніка» ORCID:https://orcid.org/0000-0002-3506-6021 e-mail: yulia.michka@gmail.com

\title{
ВИКОРИСТАННЯ УЧИТЕЛЕМ ПОЧАТКОВОЇ ШКОЛИ НАВЧАЛЬНО-МЕТОДИЧНИХ МЕДІА-КОМПЛЕКСІВ: СТАН ПРАКТИКИ
}

Постановка та обгрунтування актуальності проблеми. Формування нової школи передбачає підготовку вчителя, озброєного найсучаснішими методиками і розробками з медіа-навчання, здатного до інновацій, до впровадження Інтернет-технологій в урочну та позаурочну роботу; спроможного виховувати сучасну компетентну особистість. Тому, «пріоритетними напрямами створення цілісної системи шкільної медіа-освіти є сприяння розбудові ефективної системи медіа-освіти як складової сучасного освітнього середовища; забезпечення мультимедійними посібниками 3 медіа-освіти 3 урахуванням вікових особливостей учнів; засвоєння інформаційних технологій у позанавчальній діяльності; приєднання до освітніх європейських та світових мереж для оперативного спілкування 3 використанням сучасних засобів обміну інформації при розв'язання навчальних та науково-практичних задач» [15, с.7].
За своїми онтологічними змістами й цілями медіаосвіта діє як спосіб осягнення медіакультури, у підгрунті якого перебуває всебічне осмислення діяльності медіа, а також локально організується як особливий тип культурного (навчально-творчого) мікро- середовища, що забезпечує плідну й адекватну взаємодію особистості 3 етнонаціональними культурами. Найважливішим завданням медіаосвіти $\epsilon$ формування комплексу медіакомпетенцій як сукупності знань, умінь, норм і цінностей, що дозволяють людині осягати цілісність теперішнього ковітального повсякдення. Медіаосвіта $є$ феноменом, котрий потужно постає сьогодні на основі інтеграції освіти та інформаційно-комунікаційних технологій.

Аналіз останніх досліджень і публікацій. Дослідження різних аспектів і проблем медіа-освіти здійснюються науковцями багатьох країн. До цієї проблематики звертаються науковці, які представляють різні галузі знань, зокрема В. Биков [1], М. Бистрянцев [2], М. Імерідзе [3], А. Іщенко [4], 
Г. Онкович [11], В. Робак [14], О. Сагун [15], I. Чемерис [16], Н. Максимовська [9], О. Казанжи [5], К. Климова та О. Чупріна [6], М. Лещенко [8] та ін. Незважаючи на доволі високий ступінь дослідженості проблем медіа-освіти, значні зміни, що відбуваються як у суспільстві в цілому, так і в медіасфері зокрема, ставлять перед науковцями нові актуальні питання.

Мета статті - проаналізувати використання навчально-методичних медіа-комплексів в практичній діяльності учителя початкової школи.

Методи дослідження. Поставлене дослідницьке завдання (проаналізувати стан використання навчально-методичних медіа-комплексів на практиці, 3'ясувати причини існуючих недоліків, виявити можливості інтегративного підходу до організації навчання початковій у початковій школі, можливості та потреби учителя тощо) передбачало використання таких методів педагогічного дослідження як тестування, анкетування, експертні оцінки, вивчення педагогічного досвіду, аналіз медіа- компетентності вчителів тощо.

Виклад основного матеріалу дослідження. До складу навчально-методичного медіа-комплексу входять багатофункціональні інтерактивні мультимедійні засоби навчання, які забезпечують багаторівневу роботу з максимальною візуалізацією навчальної інформації на всіх етапах роботи з нею (передача, переробка, контроль). Його доповнюють автоматизовані програми, відео-інструкції, редагування навчальних планів, розподіл навантаження вчителів, призначення методичних днів, налаштування розкладу, розклад-автомат, уведення аудиторій в розклад, заміни вчителів тощо. Під час використання навчально-методичного медіакомплексу використовується принцип зворотного зв'язку, гнучкість вибору освітньої траєкторії, забезпечення навчального діалогу. Дослідження стану практики проводилося у закладах загальної середньої освіти).

Як свідчить аналіз, ті аспекти діяльності, які відповідають навчально-методичним медіакомплексам, функціонують в основному ізольовано. При такому підході окремі елементи управління у закладах загальної середньої освіти не спроможні забезпечити повноцінне та ефективне формування цілісної системи сучасної наочності навчання учнів.

Попереднє опитування для вияснення стану практики використання учителем початкової школи навчально-методичних медіа-комплексів проводилось серед учнів, учителів, керівників шкіл, працівників системи підвищення кваліфікації учителів.

Більшість 3 опитуваних вважають проблему формування навчально-методичних медіа-комплексів важливою, проте мало вивченою. При цьому вчителі наголошували на недостатній кількості методичної літератури 3 цих питань та на необхідності забезпечення навчання новітніми можливостями, які дають сучасні інформаційно-комунікаційні технології .
Одним 3 найважливіших завдань при розробці анкет було виявлення наявності елементів функціонування навчально-методичних медіакомплексів у практиці роботи учителів закладах загальної середньої освіти, в першу чергу початкових класів.

Доцільно зазначити, що у педагогічній практиці досить ізольовано функціонують класичний дидактичний та медіаосвітній компоненти навчальновиховного процесу, тоді як проблема одночасного їх вирішення зорієнтована на поетапне формування у сучасного вчителя інтегрованого підходу до засобів навчання, залишається малодослідженою.

Як показало дослідження, низький рівень інтеграції дидактичного та медіаосвітнього компонентів навчально-виховного процесу початкової школи утруднює формування готовності вчителя до використання навчально-методичних медіа-комплексів.

У процесі експерименту досліджувалася наявність навчально-методичних медіа-комплексів у закладах загальної середньої освіти, шляхи їх формування на основі інтегративного підходу, їх вплив на рівень сучасної наочності навчання учнів.

Вивчались також можливості окремих навчальних предметів. 3 цією метою проводився порівняльний аналіз навчальних планів і програм 3 різних дисциплін, вибіркове спостереження діяльності вчителів на заняттях. Значна частина учителів (приблизно 62\%) нечітко уявляє можливості використання навчально-методичних медіакомплексів. Результати дослідження показали, що лише $17 \%$ опитуваних спроможні визначити, що таке навчально-методичні медіа-комплекси, а $43 \%$ інтегративний підхід в цілому, надають їм належне значення та відводять відповідну роль у практиці роботи.

Водночас, багато практичних працівників вважає навчально-методичними медіа-комплексами будь-які поєднання віртуальних засобів навчання. Так, для вчителів була складена анкета, у якій пропонувалося пояснити коротко їх розуміння навчально-методичних медіа-комплексів та суті інтегративного підходу в освіті. Результати дослідження показали, що $27 \%$ опитуваних не дали відповіді взагалі (1), 35\% визначили навчальнометодичні медіа-комплекси як сукупність віртуальних засобів (2), 21\% згадали необхідність наявності зв'язків між компонентами комплексу (3). Лише $10 \%$ вказали на доцільність інтегративного підходу, який забезпечує одночасно цілісність комплексу та відносну самостійність взаємодіючих компонентів (4) та 7\% відмітили, що особливістю формування медіа-комплексів $\epsilon$ наявність чітко окресленої мети (5).

Дослідження передбачало визначення розуміння поняття «навчально-методичний медіа-комплекс» вчителями закладів загальної середньої освіти відповідно. Аналіз результатів дав можливість засвідчити, що впровадження навчально-методичних медіа-комплексів $€$ відносно новим в системі 
загальної середньої освіти та потребує додаткового вивчення. Теоретична нерозробленість проблеми формування та впровадження у навчальний процес навчально-методичних медіа-комплексів обумовлює те, що використання їх поки-що є недостатнім.

В ході експериментальної роботи приділялася значна увага роз'ясненню ролі та можливостей навчально-методичних медіа-комплексів як інтегрованих систем сучасної наочності у навчанні.

Результати анкетування виявили тенденцію до зростання значущості взаємозв'язку окремих видів засобів медіаосвіти (котрі відповідали орієнтовно змісту навчально-методичних медіа-комплексів) між собою та в межах кожного виду діяльності.

Аналіз показав, що необхідною умовою ефективної сучасної наочності навчання $є$ логічна послідовність, яка забезпечує спочатку внутрікомплексні зв'язки, а на їх основі виявляється можливість інтегративного об'єднання самих комплексів у певну медіаосвітню систему для вчителя закладах загальної середньої освіти.

Виняткове значення, на нашу думку, має забезпечення наступності у діяльності навчальнометодичних медіа-комплексів. Тому першим, найважливішим об'єктом для їх розробки та впровадження нами обрана початкова школа. Для цього була розроблена така шкала рівнів наступності 3 використанням умовних назв навчальнометодичних медіа-комплексів: «Загальні поняття та дефініції»; «Особливості медіа для початкової школи» ; «Базова підготовка вчителя до використання медіа»; «Спеціальна підготовка вчителя початкової школи до використання медіа»«Креативне використання медіа-комплексів».

Очевидно, що всі навчально-методичні медіакомплекси повинні не лише взаємодіяти, але підпорядковуватися логіці наступності. Дослідження рівнів наступності в контексті виявлення взаємодії між хронологічними аспектами комплексів дало можливість проаналізувати вертикальні зв'язки, які показують розвиток i посилення креативного компоненту у комплексах. Якщо на перших етапах суб'єктом аналізу були знання, то в п'ятому комплексі домінуючим компонентом стали медіакомпетентність та професійні якості вчителя початкових класів. Результати аналізу показали, що аспекти діяльності, які забезпечують функціонування компонентів, котрі відповідають цим навчальнометодичним медіа-комплексам, у ряді випадків координуються лише формально, на основі поверхових, часто випадкових зв'язків.

Нами було проведено дослідження потенційних можливостей реалізації пропонованих медіакомплексів у закладах загальної середньої освіти. На основі отриманого досвіду наявного використання медіа комплексів було проведено експертну оцінку перспектив їх впровадження у освітній процес. Експертами виступали вчителі початкової школи, директори закладів загальної середньої освіти, працівники відділів освіти та системи підвищення кваліфікації вчителів.
Експерти відповідати на запитання про перспективність впровадження медіа комплексів у освітній процес (варіанти відповіді - так або ні, на діаграмі представлені позитивні відповіді). Більшість експертів висловлюють позитивне ставлення до впровадження медіа-комплексів у освітній процес закладів загальної середньої освіти.

Зауважимо, що особливої уваги заслуговує навчально-методичний медіа-комплекс «Загальні поняття та дефініції» у контексті інтегративного підходу до його формування. Перш за все, підкреслимо, що метою формування та функціонування цього комплексу $є$ пошук, відбір та систематизація поняттєвого апарату медіа освіти для вчителя. Особливо це стосується вчителів середнього та старшого покоління, які не мали об'єктивної можливості засвоїти його в процесі професійної підготовки.

На цій основі було зроблено попередній висновок про доцільність розробки і реалізації саме інтегративних зв'язків між компонентами навчально-методичного медіа-комплексу. Це зумовлено тим, що інтегративний підхід в силу атрибутивних ознак інтеграції як такої, забезпечує включення всіх необхідних зв'язків при структуруванні певної сукупності елементів.

Враховано також діяльність системи підвищення кваліфікації та різноманітних курсів, однак підготовка до використання медіа комплексів у вчителів початкових класів $є$ дуже неоднорідною.

Послуговування низкою діагностичних методик (анкетування студентів, педагогів-практиків, тести, метод діагностувальних ситуацій, розгляд творчих робіт тощо) на стадії експериментального дослідження дало підстави для висновку щодо недостатньої уваги до можливостей медіаосвіти в новітніх освітніх закладах різного рівня, у превалюванні спрощених методів визначення їх місця у змісті й методичному забезпеченні навчального й виховного процесів учнів (акцентовано переважно на інформаційній функції, їхніх ілюстративних можливостях). 3-поміж педагогів-практиків поширена позиція стосовно абсолютизації негативного впливу, передусім телебачення й мережі Інтернет, на становлення дітей та юні, деструктивної функції медіа на виховання учнів. Відповідно до результатів, преса й телебачення, 3-поміж медійних зацікавлень учителів й учнів, мають неабияку перевагу.

Для практичного втілення i попередньої діагностики були застосовані авторські методики, (на прикладі предмету Образотворче мистецтво). Методикою проведення уроків образотворчого мистецтва передбачено гармонійне поєднання у структурі уроку різноманітних видів діяльності та видів мистецтва (література, музика, театр тощо). Мультимедійні засоби навчання відкривають нові технологічні можливості для педагогіки образотворення, унікальні можливості поліхудожнього виховання школярів, мають переваги порівняно 3 традиційним навчанням, допомагають 
поєднувати візуальні, музичні, театральні й інші види мистецтва.

Виявлено на практиці, що мультимедійні засоби навчання відкривають нові технологічні можливості для педагогіки образотворення, унікальні можливості поліхудожнього виховання школярів, мають переваги порівняно 3 традиційним навчанням, допомагають поєднувати візуальні, музичні, театральні й інші види мистецтва.

Висновки 3 дослідження i перспективи подальших розробок. Введення мультимедійних засобів в освітню діяльність учителя розглядається як інтегральна педагогічна проблема, а розробка відповідних методик стає щораз актуальнішою. До складу авторських методик входять автоматизовані програми, відео-інструкції, редагування навчальних планів, розподіл навантаження вчителів, призначення методичних днів, налаштування розкладу, розкладавтомат, уведення аудиторій в розклад, заміни вчителів тощо. Здійснений аналіз стану практики дав можливість зробити висновок про доцільність формування навчально-методичних медіа-комплексів на засадах інтеграції, необхідність моделювання діяльності навчально-методичних медіа-комплексів на основі науково обгрунтованих підходів та розробки шляхів їх впровадження у навчальновиховний процес початкової школи.

До подальших розвідок у даному напрямі відносимо побудову моделі навчально-методичних медіа-комплексів та іiі конкретизацію для різних навчальних дисциплін.

\section{СПИСОК ДЖЕРЕЛ}

1. Биков В.Ю., Спірін О.М., Пінчук О.П. Проблеми та завдання сучасного етапу інформатизації освіти. Наукове забезпечення розвитку освіти в Україні: актуальні проблеми теорії $і$ практики (до 25-річчя НАПН Украӥни): зб. наук. праць. Київ: ВД «Сам», 2017. С. 191-198.

2. Бистрянцев М. Створення інформаційноосвітнього простору загальноосвітньої школи. Рідна школа. 2016. № 10. C. 19-24.

3. Імерідзе М. Сутнісно-функціональний аналіз масмедіа. Психологія і суспільство. 2016. № 1. С. 109-113.

4. Іщенко А.Ю. Сучасна медіа-освіта: впровадження в Україні та міжнародний досвід. Стратегічні пріоритети. 2013. № 4 (29). С. 80-84.

5. Казанжи О.В. Формування медіакультури вчителя початкової школи: навч.-метод. комплекс навч. дисципліни для спец. 013 «Початкова освіта». Миколаїв, 2017. 123 с.

6. Климова К., Чупріна О. Проблеми та шляхи використання мультимедійних технологій у сучасній початковій школі. Актуальні проблеми лінгво дидактики: зб. наук. праць Глухівського НПУ ім. О. Довженка. Суми: Вінніченко М. Д., 2017. № 3. С. 74-78.

7. Контур Плюс / Нова Школа: програма автоматизованого складання розкладу. Мультимедійні продукти для школи: отримано гриф МОН України № 22. 1/12-Г-286 від 23.05.2018. URL: https://start.rozklad.org/ (дата звернення 09.08.2020)

8. Лещенко М.П., Тимчук Л.І. Розвиток інформаційно-комунікаційних $\mathrm{i}$ медіа компетентностей учителів у міжнародному педагогічному просторі. Інформаиійні технології $і$ засоби навчання, 2013. Т. 38. №6. C. $14-28$
9. Максимовська Н.О. Медіасоціалізація засобами анімаційної соціально-педагогічної діяльності: Програма навчальної дисципліни за вибором підготовки докторів філософії зі спеціальності 231 «Соціальна робота». Харків: ХДАК, 2016. 5 c.

10. Навчальна програма підвищення кваліфікації учителів початкових класів / укл.: М. П. Крилевець. Полтава: Полтавський обласний ін-т післядипломної пед. освіти ім. М. В. Остроградського, 2020. 9 с.

11. Онкович Г.В. Медіа-педагогіка і медіа-освіта: поширення у світі. Дивослово. 2007. № 6. С. 2 - 4 .

12. Порошенко М.А., Колупаєва А.А., Ярошук М.В. та ін. Організаційно-методичні засади діяльності інклюзивно-ресурсних центрів: навч.-метод. посібник / за заг. ред. М.А. Порошенко та ін. Київ: Обнова компані, 2018. $252 \mathrm{c}$.

13. Про підвищення кваліфікації вчителів початкової школи, які навчатимуть учнів перших класів у 2019/2020 н. p.: наказ Департаменту освіти i науки Київської міської державної адміністрації № 653 від 26. 10.2018. URL: https://ippo.kubg. edu.ua/nus (дата звернення 09.08.2020).

14. Робак В. До питання про розвиток медіапедагогіки у Німеччині. Другий украйнський педагогічний конгрес: зб. матеріалів конгресу. Львів: Камула, 2006. С. 275-286.

15. Сагун О.П. Впровадження медіа-освіти в навчально-виховний процес закладу. Всеосвіта 2018. URL: https://vseosvita.ua/library/vprovadzenna-media-osviti-v-

navcalno-vihovnij-proces-zakladu-15775.html (дата звернення 09.08.2020)

16. Чемерис I.M. Медіаосвіта за кордоном: теорії медіаосвіти та коротка історія розвитку. Вища освіта України. 2006. № 3. С. 104-108.

\section{REFERENCES}

1. Bykov, V.YU., Spirin, O.M., Pinchuk, O.P. (2017) Problemy ta zavdannya suchasnoho etapu informatyzatsiyi osvity. [Problems and tasks of the modern stage of informatization of education]. Kyiv.

2. Bystryantsev, M. (2016) Stvorennia informatsiinoosvitnoho prostoru zahalnoosvitnoi shkoly [Creation of information and educational space of secondary school].

3. Imeridze, M. (2016) Sutnisno-funktsionalnyi analiz mas-media [Essential and functional analysis of mass media].

4. Ishchenko, A.Yu. (2013) Suchasna media-osvita: vprovadzhennya $v$ Ukrayini ta mizhnarodnyy dosvid. [Modern media education: implementation in Ukraine and international experience].

5. Kazanzhy, O.V. (2017) Formuvannia mediakultury vchytelia pochatkovoi shkoly: navch.-metod. kompleks navch. dystsypliny dlia spets. 013 «Pochatkova osvita» [Formation of media culture of primary school teachers: teaching method. complex of studies disciplines for special. 013 "Primary education"]. Mykolaiv.

6. Klymova, K., Chuprina, O. (2017) Problemy ta shliakhy vykorystannia multymediinykh tekhnolohii u suchasnii pochatkovii shkoli [Problems and ways of using multimedia technologies in modern primary school]. Hlukhiv.

7. Kontur Plyus / Nova Shkola: prohrama avtomatyzovanoho skladannya rozkladu. Multymediyni produkty dlya shkoly (2018) [Contour Plus / New School: automated scheduling program. Multimedia products for school].

8. Leshchenko, M.P., Tymchuk, L.I. ( 2013) Rozvytok informatsiino-komunikatsiinykh $i$ media kompetentnostei uchyteliv u mizhnarodnomu pedahohichnomu prostori [Development of information and communication and media 
competencies of teachers in the international pedagogical space].

9. Maksymovska, N.O. (2016) Mediasotsializatsiia zasobamy animatsiinoi sotsialno-pedahohichnoi diialnosti: Prohrama navchalnoi dystsypliny za vyborom pidhotovky doktoriv filosofii zi spetsialnosti 231 «Sotsialna robota» [Media socialization by means of animation social and pedagogical activity: Curriculum of the elective training of doctors of philosophy in the specialty 231 "Social work"]. Kharkiv.

10. Krylevets, M.P. (2020) Navchalna prohrama pidvyshchennia kvalifikatsii uchyteliv pochatkovykh klasiv [Curriculum for advanced training of primary school teachers]. Poltava.

11. Onkovych, H.V. (2007) Media-pedahohika i mediaosvita: poshyrennia u sviti [Media pedagogy and media education: distribution in the world].

12. Poroshenko, M.A., Kolupayeva, A.A., Yaroshuk, M.V. ets. (2018) Orhanizatsiino-metodychni zasady diialnosti inkliuzyvno-resursnykh tsentriv. [Organizational and methodological principles of inclusive resource centers]. Kyiv.

13. Pro pidvyshchennia kvalifikatsii vchyteliv pochatkovoi shkoly, yaki navchatymut uchniv pershykh klasiv u 2019/2020 n. r.: nakaz. Departamentu osvity i nauky Kyivskoi miskoi derzhavnoi administratsii № 653 vid 26.10.2018. [About advanced training of primary school teachers who will teach first grade students in 2019/2020. $\mathrm{r}$.: order of the Department of Education and Science of the Kyiv City State Administration № 653 dated 26. 10. 2018.].

УДК 373.3.016:81(410)"19/20"

DOI: $10.36550 / 2415-7988-2020-1-191-246-249$
14. Robak, V. (2006) Do pytannia pro rozvytok mediapedahohiky $u$ Nimechchyni [On the question of the development of media pedagogy in Germany]. Lviv.

15. Sahun, O.P. (2018) Vprovadzhennia media-osvity $v$ navchalno-vykhovnyi protses zakladu. [Introduction of media education in the educational process of the institution].

16. Chemerys, I.M. (2006) Mediaosvita za kordonom: teorii mediaosvity ta korotka istoriia rozvytku [Media education abroad: theories of media education and a brief history of development]

\section{ВІДОМОСТІ ПРО АВТОРА}

МИЧКА-ЛЕВЧЕНКО Юлія Золтанівна - аспіранТ кафедри педагогіки та інноваційної освіти, Національний університет «Львівська політехніка»

Наукові інтереси: медіа-освіта, навчальнометодичний комплекс, початкова школа, інтеграція

\section{INFORMATION ABOUT THE AUTHOR}

MYCHKA-LEVCHENKO Yuliia Zoltanivna - PhD student in Professional Education, Lviv Polytechnic National University

Circle of research interests: media, media complex, educational and methodical complex, primary school, integration.

Стаття надійшла до редакиї̈ 18.09.2020 p.

ЧЕВЕЛЮК Маріанна Вікторівна аспірантка кафедри іноземної філології та перекладу, Відкритого міжнародного УНІВЕРСИТЕТУ розвитку людини "Україна" ORCID:https://orcid.org/0000-0002-2715-5024 e-mail: marianna.cheveliuk@gmail.com

\section{МОВНА ОСВІТА У ПОЧАТКОВІЙ ШКОЛІ У ВЕЛИКІЙ БРИТАНІЇ НА ПОЧАТКУ ІІ ПОЛОВИНИ ХХ СТОЛІТТЯ}

Постановка та обгрунтування актуальності проблеми. Незважаючи на очевидне значення англійської мови як засобу спілкування і літератури, вона не займала особисте місце в історії освіти, принаймні до II половини XX століття. У державних школах англійська мова довгий час була підпорядкована класиці. Перші школи для бідних зосереджувались на навчанні дітей читати Біблію. Пізніше вони мали на меті в короткий термін, перед тим, як учні пішли на роботу, навчити їх мінімальним навичкам читання, письма та шифрування, які підходили б їм для скромного та корисного працевлаштування в житті. Оскільки англійська мова на той час стала в програмі та розкладі у більшості початкових шкіл, революція настала пізніше, ніж у мистецтві, частково без сумніву, оскільки англійська мова стала одним із двох предметів, за якими оцінювали придатність до середньої освіти.

Але революція, безумовно, настала. Це почалося тоді, коли початкові школи зрозуміли, наскільки і як спонтанно діти вивчають світ та мову за чотири-п'ять років до того, як вони приходять до школи, більше, ніж вони коли-небудь знову вивчать за той же проміжок часу. Досвід та мова постійно взаємодіють; слова оживають в умовах чуттєвого та яскравого образного досвіду. Не менш вірно, що досвід стає багатшим, коли його обговорюють і відтворюють. Досягнення багатьох шкіл для молодших школярів полягало в тому, щоб розвивати та поширювати досвід дітей.

Аналіз останніх досліджень і публікацій. У серпні 1963 року Сер Едвард Бойл, тодішній міністр освіти, звернувся до Центральної консультативної ради 3 питань освіти Англії 3 проханням розглянути весь ряд предметів початкової освіти та переходу до середньої освіти.

Історії мовної освіти присвячено велику кількість зарубіжних наукових досліджень. Вагомі дослідження галузі, обрані для аналізу, представлені у працях Р.Пітерса, У.Макея, Дж.Брунера, Р.Тітоне, Л.Келлі, А.П.Р.Говатта, П.Хьорст, Р.Дирден. 